\title{
TRANSIENT ANALYSIS ON GREY CAST IRON FOAM
}

\author{
K. Sadesh ${ }^{1}$, P. V. Mohanram ${ }^{2}$, K. Gowtham ${ }^{3}$, Dane Joseph ${ }^{4}$ \\ ${ }^{1}$ Assistant Professor, Department of Mechanical Engineering, PSG College of Technology, Coimbatore, India \\ ${ }^{2}$ Professor, Department of Mechanical Engineering, PSG College of Technology, Coimbatore, India \\ ${ }^{3}$ Student, Department of Mechanical Engineering, PSG College of Technology, Coimbatore, India \\ ${ }^{4}$ Student, Department of Mechanical Engineering, PSG College of Technology, Coimbatore, India
}

\begin{abstract}
Porous materials represent a new era in the area of advanced materials. Many research works have been carried out on porous ferrous metals. This project tries to develop an open cell porous grey cast iron specimen. The method called "Casting using sand balls" was used for the development of open cell grey cast iron specimens. It consists of four stages in production such as making of sand balls, making of the mold, pouring of the molten metal, and removal of sand balls. The Transient Plane Source (TPS) experiment is done on the casted specimen to find the thermal conductivity. This experimental value of thermal conductivity of porous specimens was compared with solid specimen. A numerical analysis was also done to find out theoretical thermal conductivity which is used as thermal properties in the Finite Element (FE) Analysis of the porous model. The nodal temperature distribution was plotted for both porous and solid specimens from FEA results.
\end{abstract}

\section{Keywords - Porous grey cast iron, Thermal conductivity, TPS method}

\section{INTRODUCTION}

Metallic foams or porous metals are a new type of material and fall under subgroup of cellular metals. Porous metals are metallic materials with internal pores which are interconnected. Metallic foams have many attractive combinations of mechanical and physical properties such as high impact energy absorption capabilities with low densities, high temperature tolerance etc. According to their internal structure, the metallic foams are mainly classified into three types. They are open cell, closed cell and combination of two. Open celled foams allow fluid transfer through it due to it has interconnected pores up to surfaces and therefore it can be used in heat exchangers, filters etc. Closed cell foam has nearby sealed pores. So, the fluid transfer is not possible through it. It will be useful for structural applications like car bumpers, building and bridges.

Louis-Philippe Lefebvre et.al[1] discovered that technology for foamed and spongy material evolving in fast pace and this research area is multidisciplinary in nature involving physics, chemistry, material science. Aluminum foams are most widely researched metal foams. Rossella Surace et.al[2] investigated and compared different manufacturing techniques for aluminum foams. John Banhart[3] classifies general process routes according to the various forms of metals used such as metal vapor, liquid metal, powdered metal, and metallic ion. N.Babcsán et.al[4] also helped in classification of manufacturing processes and studied about the physics behind it. Steel foams grow as interesting research area in present days. B.H Smith et.al[5] studied various properties and manufacturing methods and potential applications for the steel foams. Casting routes using liquid metals have less processing time and cost than other process routes. P.Lichy et.al[6] explained different casting techniques for porous metals. A.K.Shaik Dawood et.al[7] found out pores can be developed using filler materials (sand balls) and core boxes can be used for making of uniform sized sand balls. The same method is applied on gun metal and testified by S.Sridhar et.al[8]. E. Solórzano et.al[9] explains the transient plane source method on aluminium foam with working principle and experimental procedure. M.F. Ashby et.al[10] gave an insight over the numerical analysis by developing empirical relations over different parameters which influence the properties of the porous metals and production techniques.

Cast iron is the one of the oldest ferrous metals used in construction and outdoor ornament. It is primarily composed of iron $(\mathrm{Fe})$, carbon $(\mathrm{C})$ and silicon $(\mathrm{Si})$, but may also contain traces of sulphur $(\mathrm{S})$, manganese $(\mathrm{Mn})$ and phosphorous $(\mathrm{P})$. It has a relatively high carbon content of $2 \%$ to $5 \%$. It is hard, brittle, non-malleable and more fusible than steel. Its structure is crystalline and relatively brittle and weak in tension. Cast iron is very good in compression loads. The most common traditional form is grey cast iron. Common or grey cast iron can be easily cast but it cannot be forged or worked mechanically either hot or cold. In grey cast iron, the carbon content is the form of flakes distributed throughout the metal.

In the present work, The TPS method is used for the experimentation of thermal conductivity of different specimens. The specimens used in this experiment are developed using a relatively new sand casting technique which makes use of sand balls to create the internal pores. Experimental results on both solid and porous specimens are compared and found to be in good agreement. Thermal conductivity for porous grey cast iron is calculated analytically using empirical relations with different values of porosity. Finite element models for porous metals and solid 
metal are also developed. These models are used to find out the temperature distribution in the material.

\section{MANUFACTURING}

The specimen is prepared using casting by sand ball technique (casting using core balls). It is a manufacturing process by which a liquid material is usually poured into a mould which contains a hollow cavity of the desired shape with sand balls, and allowed to solidify. The solidified part is also known as a casting which is ejected or broken out of the mould to complete the process. The sand ball preparation and casting processes are done in the PSG \& SON'S Charities Metallurgy and Foundry Division. In this process, the following four steps are done, such as preparation of fillers (sand balls), preparation of mould, pouring of molten metal, and removal of sand balls.

The sand balls are prepared using core boxes. Core box gives uniformly sized balls. Two core boxes of sand ball diameter $15 \mathrm{~mm}$ and $20 \mathrm{~mm}$ is manufactured using CNC vertical milling machine which is available in the PSG Tool and die making centre. The core boxes are shown in Figure 1.

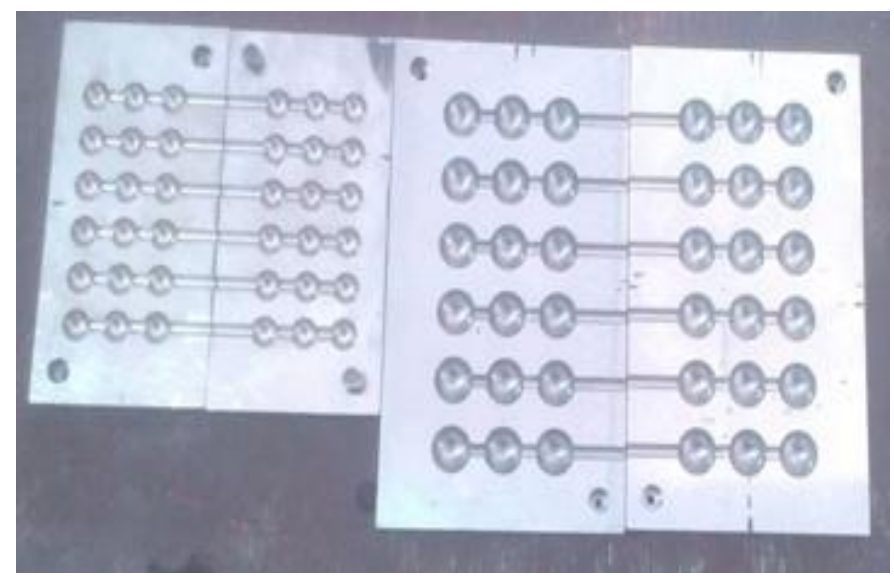

Fig 1: Core boxes

Table 1: composition of furan sand mixture

\begin{tabular}{|l|l|}
\hline Constituents & Percentage \\
\hline Furan sand & $50 \%$ \\
\hline Catalyst & $40 \%$ \\
\hline Resin(alcohol + phenol) & $10 \%$ \\
\hline
\end{tabular}

The sand balls are casted using furan sand mixture. The composition of the mixture is given in Table 1.

Percentage of catalyst decides the setting time for the sand ball. It takes approximately half an hour as setting time for this given composition. Resin is acting as a binder for all the constituents. Mixing of FURAN sand is done by a mixing machine called OMEGA SPARTAN 3. If sand is not rammed after it is filled in cavity, sand balls will have a hemispherical shape. Sand ball should be preheated using flame for acquiring required strength to withstand the high temperature and weight of the molten metal. Sand balls are dipped in a coat of graphite and spirit before preheating.
Wooden pattern of size (60mm diameter, $40 \mathrm{~mm}$ height $)$ was used to produce a mould by using FURAN sand mixture. The sand balls were filled in to the mould cavity up to the top of cavity. The mould is designed to get full cavity under the partition line. Therefore, full cavity is in drag box. Sand casting done with molding box of $(640 \mathrm{~mm} \mathrm{X} 480 \mathrm{~mm} \mathrm{X}$ $150 \mathrm{~mm}$ ) made of ply wood was used. Mould is preheated to get maximum strength.

The cope and drag moulds are joined together using industrial glue to avoid the leakage of the molten metal. The grey cast iron FG 260 is used for casting. The chemical composition of grey cast iron FG 260 is shown in Table 2.

Table 2: chemical composition of fg260 grey cast iron

\begin{tabular}{|l|l|l|l|l|l|l|l|l|l|}
\hline $\begin{array}{l}\text { Eleme } \\
\text { nt }\end{array}$ & $\mathbf{C}$ & $\mathbf{S i}$ & $\mathbf{M n}$ & $\mathbf{P}$ & $\mathbf{S}$ & $\begin{array}{l}\mathbf{C} \\
\mathbf{u}\end{array}$ & $\begin{array}{l}\mathbf{C} \\
\mathbf{r}\end{array}$ & $\mathbf{N i}$ & $\mathbf{T i}$ \\
\hline $\boldsymbol{\%}$ & 3. & 2. & .83 & .0 & .0 & .6 & .5 & .0 & .027 \\
& 2 & 2 & & 5 & 4 & & & 4 & \\
\hline
\end{tabular}

Gray cast iron was melted in induction furnace and the metal is poured into the mould at a temperature range of $1380^{\circ} \mathrm{C}$ $1385^{\circ} \mathrm{C}$. Solidifying time is approximately 2 hours. Some weight is placed over the mould to avoid the lifting of the cope box and hence avoiding leakage of molten metal.

Table 3: porosity of specimen

\begin{tabular}{|c|c|c|c|c|}
\hline $\begin{array}{l}\text { Sl } \\
\text { No }\end{array}$ & $\begin{array}{l}\text { Specimen } \\
\text { type }\end{array}$ & $\begin{array}{l}\text { Specimen } \\
\text { set no }\end{array}$ & $\begin{array}{l}\text { Density } \\
\left(\mathrm{Kg} / \mathbf{m}^{3}\right)\end{array}$ & $\begin{array}{l}\text { Porosity } \\
(\%)\end{array}$ \\
\hline 1 & Solid & A1 & 7150 & 0 \\
\hline 2 & \multirow{6}{*}{$\begin{array}{l}\text { Porous } \\
\text { type-1 } \\
(15 \mathrm{~mm} \\
\text { sand ball) }\end{array}$} & B1a & 2829 & 60.4 \\
\hline 3 & & B1b & 3006.2 & 57.9 \\
\hline 4 & & B2a & 3183 & 55.5 \\
\hline 5 & & $\mathrm{~B} 2 \mathrm{~b}$ & 3006.2 & 57.9 \\
\hline 6 & & B3a & 2829.4 & 60.4 \\
\hline 7 & & B3b & 3182 & 55.5 \\
\hline 8 & \multirow{6}{*}{$\begin{array}{l}\text { Porous } \\
\text { type- } 2 \\
\text { (20mm } \\
\text { sand ball) }\end{array}$} & C1a & 2971.8 & 59.2 \\
\hline 9 & & $\mathrm{C} 1 \mathrm{~b}$ & 3536.7 & 50.5 \\
\hline 10 & & $\mathrm{C} 2 \mathrm{a}$ & 2917.8 & 59.2 \\
\hline 12 & & $\mathrm{C} 2 \mathrm{~b}$ & 3183 & 55.5 \\
\hline 13 & & $\mathrm{C} 3 \mathrm{a}$ & 3536.7 & 50.5 \\
\hline 14 & & $\mathrm{C} 3 \mathrm{~b}$ & 3183 & 59.2 \\
\hline
\end{tabular}

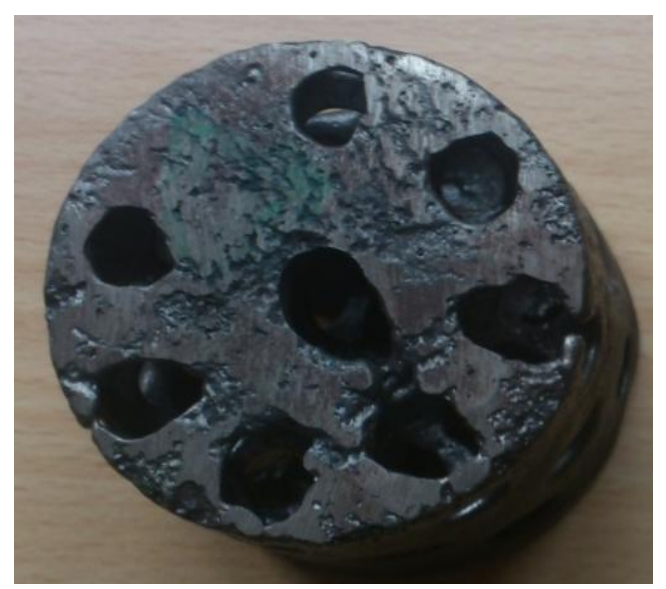

Fig 2: Manufactured specimen 
The casting is taken out by breaking the mould using shaker machine. The sand balls are in powder form after the solidification. It can be easily removed from the casting through the pores by shot blasting machine. Prepared specimen is shown in Figure 2. The porosity of specimens can be calculated using the following formula. The porosity of porous and solid specimens is given in Table 3 .

\section{$\%$ Porosity $=$ (B utk casting den - Produced asting den $)$ s 100}

\section{EXPERIMENT SETUP AND DETAILS}

The thermal conductivity of the prepared specimen is measured using Transient Plane Source (TPS) method. The principle of this method depends on a plane element which acts as heat source and sensor. The heat is generated by coil made of constantan wire. The coil is wrapped inside insulating layer of kapton sheet. It ensures uniform heat distribution throughout the specimen. The TPS element is sandwiched between two similar specimens. This method has some advantages over other standard methods such as fastness and simplicity, wide range of measurable thermal conductivity $\left(0.04 \mathrm{~W} / \mathrm{m}^{\circ} \mathrm{C}-400 \mathrm{~W} / \mathrm{m}^{\circ} \mathrm{C}\right)$, less effort on specimen preparation, and flexibility in specimen size.

\subsection{Experimental Setup}

Experimental setup of TPS method consists of specimen container made of wood, heating coil, pair of specimen, thermocouple and outer cover as shown in the Figure 3. The thermocouple is interfaced to LABVIEW using DAQ card (NI 9211). The specimens are to be placed inside the container and heating coil is placed in between them. The container tightened and heating coil is connected to DC power supply. The experimental setup is shown in the Figure 4. Two cylindrical specimens are used, one of which is drilled at the centre to place the thermocouple.

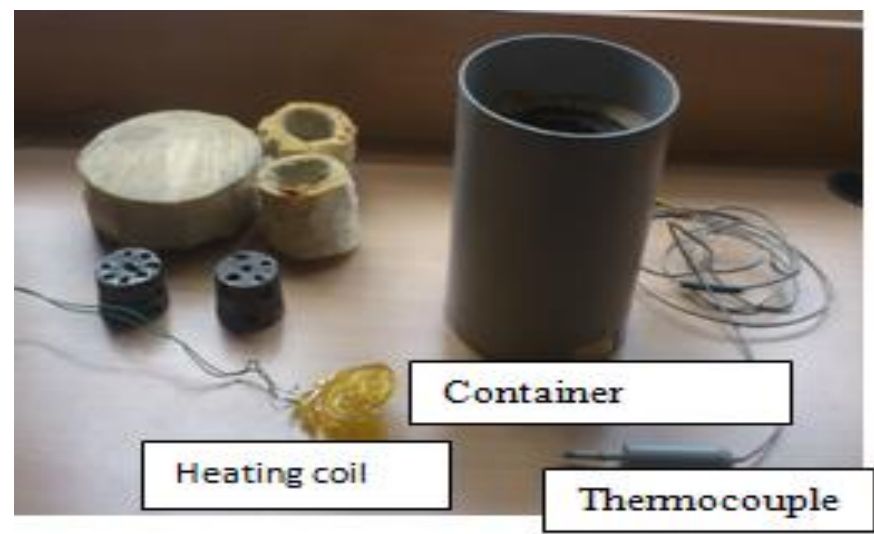

Fig 3: Components in TPS experiment

The specimens are prepared in the PSG Foundry Division. The experiment requires point type sensor. Thermocouple is used as temperature sensor. Thermocouple is insulated to avoid contact with specimen.

\subsection{Experimental Procedure}

The DC power supply is switched on and the required voltage and current is adjusted. The data acquisition system is switched $\mathrm{ON}$ and required program is loaded in LabVIEW software. The whole setup is left for sometime say 10 minutes to achieve thermal equilibrium which will avoid initial lag error.

The LabVIEW software is made to run and variation of temperature is recorded down using MS EXCEL spreadsheet. The power supply is switched OFF and set up is left free for some time. Once the specimen is cooled down to room temperature, the specimen is taken out and the container is cleaned thoroughly. The output of LABVIEW is exported in an MS EXCEL spreadsheet for calculation. The setup should be cooled down to room temperature before repeating experiments.

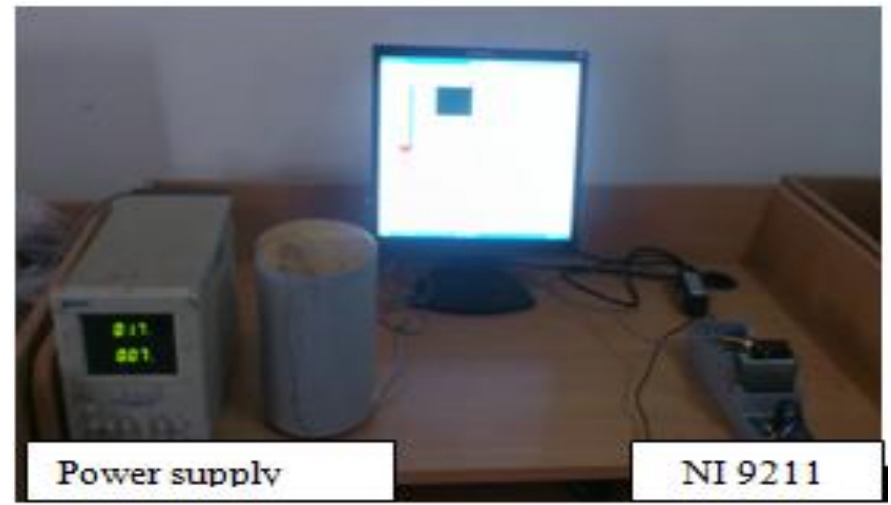

Fig 4: Experimental setup

\subsection{Experimental Results.}

The variation of temperature within the time period is plotted using graphical representation of temperature $\mathrm{v} / \mathrm{s}$ natural logarithm of the time. This graph is used for the calculation of the thermal conductivity. The Figure 5 shows the graph between Thermal conductivity $\mathrm{v} / \mathrm{s} \ln (\mathrm{t})$ for specimen set no. C1.

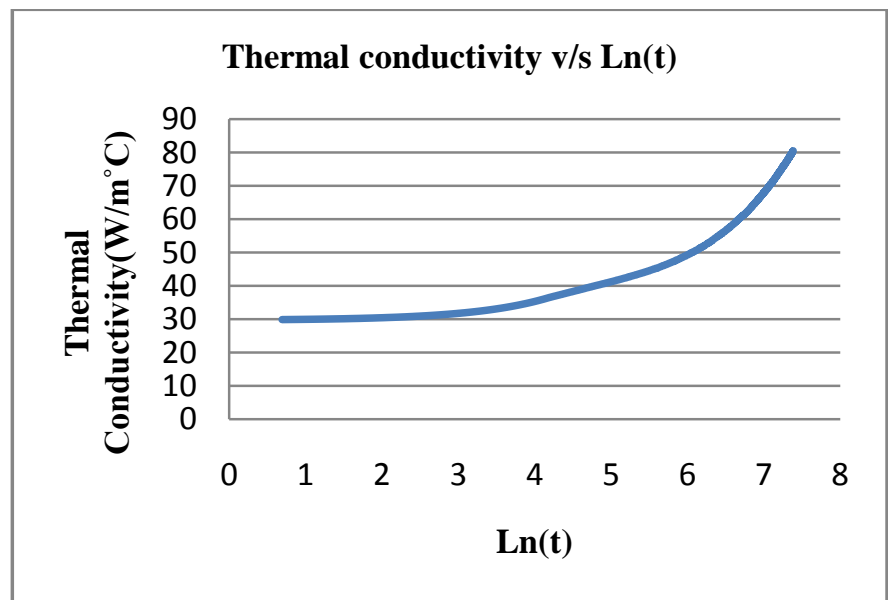

Fig 5: Thermal conductivity $v / s \ln (t)$ for porous specimen set no $\mathrm{C} 1$ 
Thermal conductivity can be calculated using the following formula.

$$
k=\frac{q}{\pi^{3 / 2} \cdot r \cdot m}
$$

Where,

$\mathrm{k}$ is the thermal conductivity $\left(\mathrm{W} / \mathrm{m}^{\circ} \mathrm{C}\right)$

$\mathrm{q}$ is the input $\operatorname{power}(W)=V \times I$

$\mathrm{r}$ is the radius of the heaing coil $=0.03 \mathrm{~m}$

$\mathrm{m}$ is the slope from the graph

$\mathrm{V}$ is the voltage $(\mathrm{V})$

I is the current (A)

The average thermal conductivity for the solid and porous specimens is calculated and recorded in Table 4. Table 5 shows variation of thermal conductivity with temperature for different porous and solid models.

Table 4: average thermal conductivity of specimens

\begin{tabular}{|c|c|c|c|c|c|}
\hline $\begin{array}{l}\text { Speci } \\
\text { men } \\
\text { type }\end{array}$ & \begin{tabular}{ll}
\multicolumn{2}{c}{ Specim } \\
en set \\
no
\end{tabular} & $\begin{array}{l}\text { Vol } \\
\text { tag } \\
\text { e } \\
\text { (V) }\end{array}$ & $\begin{array}{l}\text { Curren } \\
\mathbf{t} \\
\text { (A) }\end{array}$ & $\begin{array}{l}\text { Power } \\
\text { (W) }\end{array}$ & $\begin{array}{l}\text { Average } \\
\text { thermal } \\
\text { conductivi } \\
\text { ty } \\
\left(\mathbf{W} / \mathbf{m}^{\circ} \mathrm{C}\right)\end{array}$ \\
\hline Solid & A1 & 11.3 & 2.01 & 22.71 & 49.59 \\
\hline \multirow{3}{*}{$\begin{array}{l}\text { Porous } \\
\text { type-1 } \\
\text { (20mm } \\
\text { sand } \\
\text { ball) }\end{array}$} & B1 & 11.1 & 1.99 & 22.09 & 13.6 \\
\hline & B2 & 10.8 & 1.87 & 20.196 & 18.43 \\
\hline & B3 & 11.3 & 1.99 & 22.83 & 10.71 \\
\hline \multirow{3}{*}{$\begin{array}{l}\text { Porous } \\
\text { type-2 } \\
(20 \mathrm{~mm} \\
\text { sand } \\
\text { ball) }\end{array}$} & $\mathrm{C} 1$ & 11.0 & 1.95 & 21.45 & 9.26 \\
\hline & $\mathrm{C} 2$ & 10.7 & 1.87 & 20.01 & 8.2 \\
\hline & C3 & 11.3 & 2 & 22.6 & 12.84 \\
\hline
\end{tabular}

Table 5: variation of thermal conductivity of specimens with temperature

\begin{tabular}{|l|l|l|l|l|l|l|l|l|}
\hline $\begin{array}{l}\text { Sl } \\
\text { No }\end{array}$ & $\begin{array}{l}\text { Tem } \\
\text { perat } \\
\text { ure } \\
\left({ }^{\circ} \mathbf{C}\right)\end{array}$ & $\begin{array}{l}\text { Thermal conductivity } \\
\left(\mathbf{W} / \mathbf{m}^{\circ} \mathbf{C}\right)\end{array}$ \\
\hline & & $\begin{array}{l}\text { Soli } \\
\text { d }\end{array}$ & \multicolumn{3}{|l|}{ Porous type-1 } & \multicolumn{3}{l|}{ Porous type-2 } \\
\hline & & A1 & B1 & B 2 & B 3 & C1 & C 2 & C3 \\
\hline 1 & 40 & 53.8 & 31.2 & 32.2 & 30.9 & 26.4 & 15.4 & 41.8 \\
\hline 2 & 50 & 53.7 & 19.5 & 26.4 & 9.6 & 8.09 & 10.5 & 10.7 \\
\hline 3 & 60 & 53.5 & 8.4 & 15.3 & 5.7 & 5.21 & 6.65 & 5.9 \\
\hline 4 & 70 & 46.3 & 5.1 & 11.2 & 4.06 & 3.65 & 4.74 & 4.2 \\
\hline 5 & 80 & 40.7 & 3.9 & 7.04 & 3.2 & 2.97 & 3.88 & 1.63 \\
\hline & & & & & & & & \\
\hline
\end{tabular}

\section{NUMERICAL ANALYSIS}

The thermal conductivity of porous metal is related to the relative density by following relation.

$$
\lambda=\lambda_{s} *\left(\frac{\rho}{\rho_{s}}\right)^{1.7}
$$

Where,

$\lambda$ is thermal conductivity of porous $\operatorname{metal}\left(\mathrm{W} / \mathrm{m}^{\circ} \mathrm{C}\right)$

$\lambda_{\mathrm{s}}$ is thermal conductivity of base metal $=51 \mathrm{~W} / \mathrm{m}^{\circ} \mathrm{C}$

Thermal conductivity for porous grey cast iron is calculated at different porosities ranging from 0.1 to 1 which is shown graphically in Figure 6.

\section{Thermal conductivity v/s Relative density}

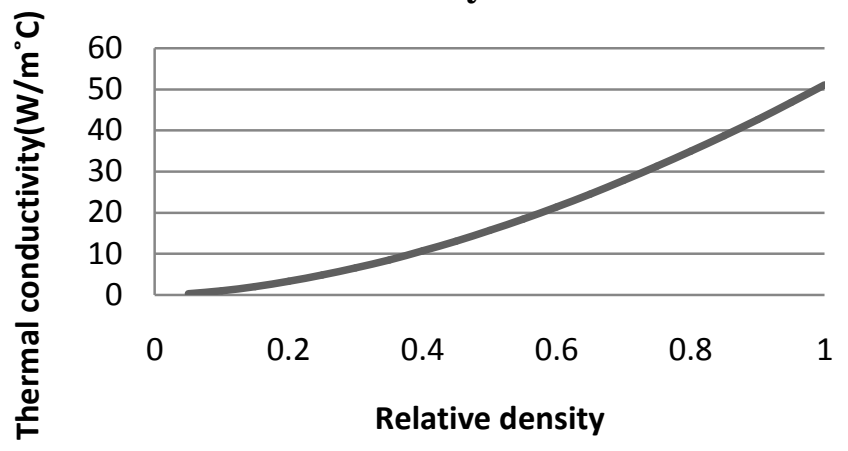

Fig 6: Variation of thermal conductivity with relative density

\section{FINITE ELEMENT ANALYSIS}

Finite element analysis is done on solid and porous cast iron models to compare the nodal temperature distribution. Heat flux is used as heat input. Different values of heat flux are used and results are analyzed.

\subsection{Material Properties}

The material properties used for both solid and porous models are listed in Table 6.

Table 6:- material properties

\begin{tabular}{|l|l|l|l|}
\hline Models & $\begin{array}{l}\text { Density } \\
\left(\mathbf{k g} / \mathbf{m}^{\mathbf{3}}\right)\end{array}$ & $\begin{array}{l}\text { Porosity } \\
(\%)\end{array}$ & $\begin{array}{l}\text { Thermal } \\
\text { conductivity } \\
\text { (w/mk) }\end{array}$ \\
\hline $\begin{array}{l}\text { Solid cast } \\
\text { iron }\end{array}$ & 7200 & 0 & 50 \\
\hline $\begin{array}{l}\text { Porous cast } \\
\text { iron type-1 }\end{array}$ & 3006 & 58.3 & $11.32^{\#}$ \\
\hline $\begin{array}{l}\text { Porous cast } \\
\text { iron type-2 }\end{array}$ & 3212.5 & 55.4 & $12.68^{\#}$ \\
\hline
\end{tabular}

\# According to numerical calculation (Eqn. 3) 


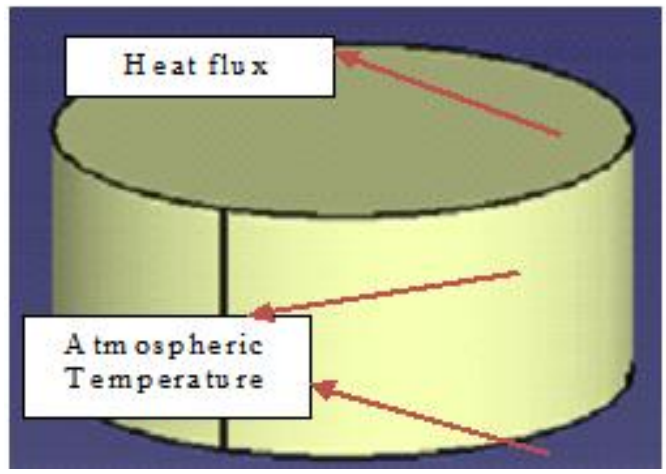

Fig 7: Specimen model for solid cast iron

\subsection{Specimen Model}

The Figure 7 shows the solid model and location where heat flux is applied. Convection heat transfer is neglected.

\subsection{Meshed Model}

The model is meshed with Solid278 element which has 3Dthermal conductivity capabilities. It has 8 nodes and single degree of freedom, temperature at each node. Meshed model of porous type- 2 is shown in Figure 8.

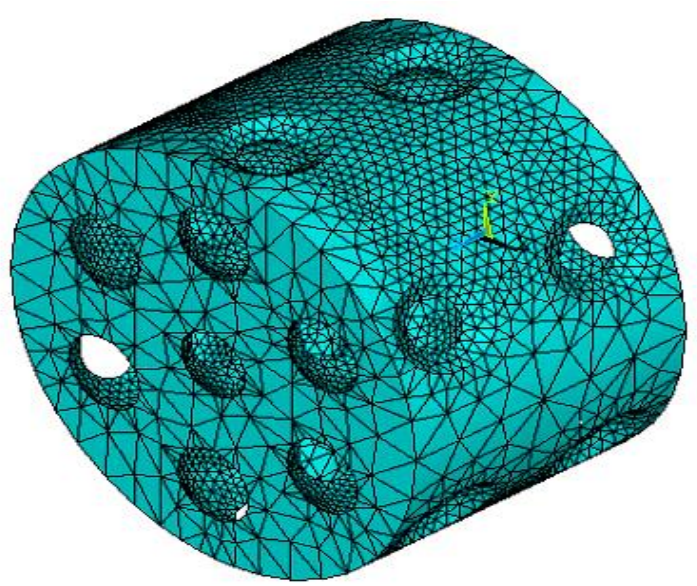

Fig 8: Meshed model for porous type-2

\subsection{Finite Element Analysis Results}

The analysis is made for heat flux 10, 20, 30, 40 and 50 $\mathrm{W} / \mathrm{m}^{2}$. The results are shown in the Table 7 .

Table 7: the maximum nodal temperature for models

\begin{tabular}{|l|l|l|}
\hline Model & $\begin{array}{l}\text { Heat } \\
\text { Flux }\left(\mathbf{W} / \mathbf{m}^{\mathbf{2}}\right)\end{array}$ & $\begin{array}{l}\text { Maximum } \\
\text { nodal } \\
\text { temperature }\left({ }^{\circ} \mathbf{C}\right)\end{array}$ \\
\hline \multirow{4}{*}{ Solid cast iron } & 10 & 31.05 \\
\cline { 2 - 3 } & 20 & 34.1 \\
\cline { 2 - 3 } & 30 & 37.15 \\
\cline { 2 - 3 } & 40 & 40.2 \\
\cline { 2 - 3 } Porous cast & 50 & 43.26 \\
\hline iron type-1 & 10 & 96.2 \\
\cline { 2 - 3 } & 20 & 164.3 \\
\hline
\end{tabular}

\begin{tabular}{|l|l|l|}
\hline (ball dia-15) & 40 & 300.7 \\
\cline { 2 - 3 } & 50 & 368.8 \\
\hline \multirow{3}{*}{\begin{tabular}{l} 
Porous cast $\begin{array}{l}\text { iron type-2 } \\
\text { (ball dia-20) }\end{array}$ \\
\cline { 2 - 3 }
\end{tabular}} & 10 & 79.7 \\
\cline { 2 - 3 } & 20 & 131.4 \\
\cline { 2 - 3 } & 40 & 183 \\
\cline { 2 - 3 } & 50 & 234.8 \\
\hline
\end{tabular}

The nodal temperature distribution of porous type-1 at 40 $\mathrm{W} / \mathrm{m}^{2}$ is shown in Figure 9.

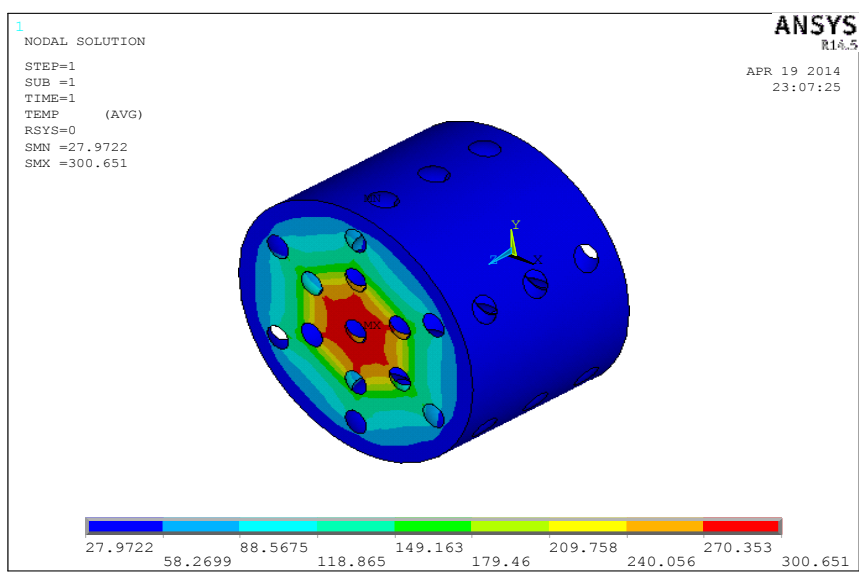

Fig 9: The nodal temperature distribution on porous type-1 at $40 \mathrm{~W} / \mathrm{m}^{2}$

\section{RESULTS AND DISSCUSSION}

The thermal conductivity of specimen is declining with increment in the temperature. The reason for this behavior of metals can be explained by the fact that free electrons which causes the thermal transport collide with other atoms in the metallic object. Their kinetic energy is wasted to some extent due to these collisions. When the temperature increases, these collisions increases, as losses in kinetic energy increases. This obviously reduces their thermal and electrical conductivity. The variation of thermal conductivity is shown in Figure 10. The experimental results for both solid and porous specimens are compared in Table 8.

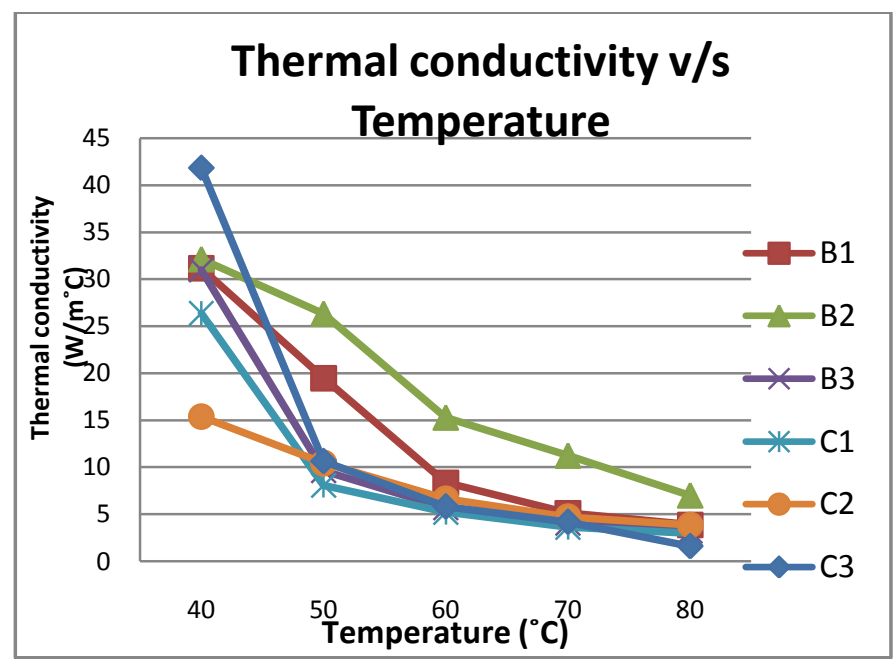

Fig 10: Variation of thermal conductivity with temperature 
Table 8: The comparison of numerical and experimental thermal conductivity

\begin{tabular}{|c|c|c|c|}
\hline $\begin{array}{l}\text { Sl } \\
\text { No }\end{array}$ & Porous type & $\begin{array}{l}\text { Experiment } \\
\text { al } \\
\text { Conductivit } \\
\text { y } \\
\left(\mathbf{W} / \mathbf{m}^{\circ} \mathrm{C}\right)\end{array}$ & $\begin{array}{l}\text { Percentag } \\
\text { e of of } \\
\text { reduction } \\
(\%)\end{array}$ \\
\hline 1 & Solid & 49.59 & 0 \\
\hline 2 & \multirow[t]{3}{*}{ Porous type-1 } & 13.6 & 72.6 \\
\hline 3 & & 18.4 & 62.9 \\
\hline 4 & & 10.7 & 78.4 \\
\hline 5 & \multirow[t]{3}{*}{ Porous type- 2} & 9.26 & 81.3 \\
\hline 6 & & 8.2 & 83.5 \\
\hline 7 & & 12.84 & 74.1 \\
\hline
\end{tabular}

The FEA results show that the porous type 1 has a higher maximum nodal temperature than porous type 2 and solid model. It is due to the localized temperature rise because of presence of pores in the structure. As a future work, transient thermal analysis should be done to validate the decrement of thermal conductivity with rise in temperature according to Fourier's law.

\section{CONCLUSIONS}

The casting using sand balls for porous metals seems to be cheaper and easier than other methods. The maximum porosity achieved by this method is $60.4 \%$. The TPS method is a powerful tool for calculating thermal conductivity for porous metals. The results show that the thermal conductivity decreases with rise in temperature. The maximum average thermal conductivity is achieved from porous type- 1 specimen as $18.4 \mathrm{~W} / \mathrm{m}^{\circ} \mathrm{C}$ and minimum thermal conductivity is achieved from porous type- 2 as $8.2 \mathrm{~W} / \mathrm{m}^{\circ} \mathrm{C}$. It has $83.5 \%$ reduction in thermal conductivity when comparing with solid specimen. This property enables it to be used in industrial chill forms and metal-ceramic heat shields.

\section{REFERENCES}

[1]. Louis-Philippe Lefebvre "Porous metals and metallic foams: current status and recent developments", Adv.Engg.Mat, vol 10(9), 775-787, 2008

[2]. Rossella Surace, and Luigi A.C. De Filippis "investigation and comparisson of aluminium foam manufactured by different techniques.”,457-489,2007

[3]. John Banhart "Light-metal foams - history of innovation and technological challenges" Adv.Engg.Mat ,10.1002, 2013

[4]. N. Babcsán, J. Banhart, and D. Leitlmeier "Metal Foams - Manufacture and Physics of Foaming" Materials Transactions 2007

[5]. B.H. Smith, S. Szyniszewski "Steel foam for structures: A review of applications, manufacturing and material properties" journal of constructional steel research, 2011

[6]. P. Lichy "Casting routes for porous metals production" archives of foundry engg: Volume 12 Issue 1/2012, 2012

[7]. A. K. Shaik dawood, and S.S.Mohamed Nazirudeen "A Development of Technology for Making Porous Metal Foams Castings" JJMIE, Volume 4, Number 2, March. 2010. [8]. Sridhar, S.S.Mohamed Nazirudeen,and M.Kavitha "Production of Gunmetal Foam-A Novel Technique",
International Journal of Engineering Science and Technology Vol. 2(10), 2010

[9]. E. Solórzano, J.A. Reglero, M.A. Rodríguez-Pérez, D. Lehmhus, M. Wichmann, and J.A. de Saja " An experimental study on the thermal conductivity of aluminium foams by using the transient plane source method" journal of heat and mass transfer, pp 6259-6267, 2008

[10]. M.F. Ashby, A.G. Evans, N.A. Fleck, L.J. Gibson,J.W. Hutchinson and H.N.G. Wadley "Metal Foams: A Design Guide", Butterworth Heinemann publishers, 2000 